\title{
ECOCULTURAL HERITAGE, TOURISM DEVELOPMENT AND MANAGEMENT POLICIES. CONTRIBUTIONS TO THE VALORISATION OF THE CROSS BORDER MOUNTAINS OF THE CORDILLERA CENTRAL
}

PATRIMÓNIO ECOCULTURAL, DESENVOLVIMENTO TURÍSTICO E POLÍTICAS DE GESTÃO. CONTRIBUTOS PARA A VALORIZAÇÃO DAS SERRAS TRANSFRONTEIRIÇAS DA CORDILHEIRA CENTRAL PATRIMONIO ECO CULTURAL, DESARROLLO TURÍSTICO Y POLÍTICAS DE GESTIÓN. CONTRIBUTOS PARA LA VALORIZACIÓN DE LAS SIERRAS TRANSFRONTERIZAS DE LA CORDILLERA CENTRAL

Gonçalo José Poeta Fernandes (goncalopoeta@pg.pt)*

\begin{abstract}
Mountain areas have witnessed a growing Eco-cultural and touristic appreciation due to their natural and cultural resources and the perception of integrity and authenticity associated with them. However, in Portugal, the mountains have stayed away from specific territorial strategy interventions as well as guidelines for concerted tourism development. It appears that the practices of recreation and leisure are becoming wider, which implies new forms of tourism and environmental planning.

The traditional economic structure of the Cordillera Central Mountains has been uncoordinated with the reconfiguration of lifestyles, while preserving many of the elements belonging to their cultural identity and heritage, with motivations and connotations preferably related to tourism activities. This has been a dynamic factor of economic and social regeneration, promoting services that improve the welfare and value of existing resources. However, there is no integrated territorial management and tourism policy. In this context, the aim of the research is to highlight the Ecocultural value of these territories and the absence of concerted strategies of articulation and public management of these border mountains and tourist activities associated.
\end{abstract}

Keywords: Mountain, Tourism, Public Policy, Environment and Heritage

\section{RESUMO}

Os territórios de montanhas têm verificado uma crescente valorização ecocultural e interesseturístico, face aos recursos naturais e culturais que albergam, assim como à percepção de integridade e autenticidade que Ihe estão associadas. Contudo, em Portugal, as montanhas têm ficado afastadas de políticas de intervenção com especificidade territorial, bem como de orientações concertadas para o fomento do turismo e para o seu desenvolvimento. Verifica-se que as práticas de recreio e lazer são cada vez mais alargadas, o que implica novas formas de planeamento turístico e ambiental.A estrutura 


\section{Egitania \\ s c i e $\Omega$ c i a}

económica tradicional das serras da Cordilheira Central tem-se desarticulado, com a reconfiguração dos modos de vida, mas preservando muitas das suas identidades culturais e elementos patrimoniais que promovem novas formas de apropriação, com motivações e conotações preferencialmente relacionados com as atividades turísticas. Esta dinâmica tem constituído um fator de revitalização económica e social, fomentando serviços que incrementam o bem-estar e valorizam os recursos existentes. Contudo, não existe uma política articulada de gestão e a valorização integrada do turismo. Neste contexto, é objetivo da investigação evidenciar o potencial ecocultural destes territórios e a ausência de estratégias concertadas de articulação e gestão publica destas serras de fronteira e das atividades turísticas associadas.

Palavras-Chave: Montanha, Turismo, Politicas públicas, Ecocultura e Património.

\section{RESUMEN}

Los territorios de montaña han constatado una creciente valorización eco cultural e interés turístico, cara a los recursos naturales y culturales que albergan y a la percepción de integridad y autenticidad a que se encuentran asociadas. Entretanto en Portugal, las zonas de montaña han quedado apartadas de las políticas de intervención con especificidad territorial, así como de orientaciones concertadas para el fomento del turismo y para su desarrollo. Se verifica que las prácticas de recreo y ocio se amplian cada vez más, lo que implica nuevas formas de planeamiento turístico y ambiental.

La estructura económica tradicional de las sierras de la Cordillera Central se ha desarticulado, con la reconfiguración de los modos de vida, pero preservando muchas de sus identidades culturales y elementos patrimoniales que promueven nuevas formas de apropiación, con motivaciones y connotaciones preferencialmente relacionadas con las actividades turísticas. Esta dinámica ha constituido un factor de revitalización económico y social, fomentando servicios que incrementan el bienestar y valorizan los recursos existentes. Sin embargo, no existe una politica articulada de gestión ni de valorización integrada del turismo. En este contexto es objetivo de la investigación destacar el potencial eco cultural de estos territorios y la ausencia de estrategias concertadas de articulación y gestión publica de las sierras fronterizas y de las actividades turísticas que le están asociadas. En este contexto es objetivo de la investigación destacar el potencial eco cultural de estos territorios y la ausencia de estrategias concertadas de articulación y gestión publica de las sierras fronterizas y de las actividades turísticas que le están asociadas.

Palabras-Clave: Montaña, Turismo, Políticas públicas, Eco cultura y Patrimonio

*Unidade de Desenvolvimento para o Interior - UDI/IPG

CICS.NOVA - Interdisciplinary Centre of Social Sciences

Submitted: 7th June 2015

Accepted: 13th July 2015 


\section{Egitania \\ $s$ c i e $\cap$ c i a}

\section{INTRODUCTION}

The mountain areas are spaces of great heritage value, which is evidenced by geomorphological aspects, climatic characteristics, landscape features, specific ways of life, forms of occupation and cultural marks. The knowledge of their heritage involves an integrated approach of its multiple factors, whether they constitute a natural heritage or those resulting from the historical development of their communities. These territories are powerful elements of the Iberian borders, both for its size and geography resources they hold, either for their role in the connections between countries and communities. These Iberian mountains require an intervention that allow them to consolidate their uses and functions and to assume themselves fully and valued way as equity transnational spaces that can be converted into international eco cultural parks. The problems and weaknesses, today recognized, call for appropriate policy The problems and weaknesses, today recognized, call for na appropriate policy, articulating the coexistence of uses and functions in a scenario tending to change due to the ecological, social and economic role they pose to communities.

\section{THE BORDER MOUNTAINS: REPRESENTATION, PERCEPTION AND ECOCULTURAL VALUE}

The transformations experienced by mountain regions, especially in the last half century, have led to a different perception with expectations, actors and problems that led to the reconfiguration of the productive bases, social organization and landscapes. Many of their activities were frozen in time, registering distance from progress models of adjacent territories, especially those of urban nature. Nowadays we witness a general revaluation ${ }^{1}$ of the mountain that rewards the natural and cultural qualities of these territories. These perceptual changes, and even occupation, mean that these areas before isolated and hostile due to natural constraints, today have a distinct ownership as a result of their knowledge and opening to the outside (GASCÓN, J., 2013). Increased accessibility, use of resources, dissemination of ecocultural values, the extension of recreation and leisure activities and the increase of visitor flows have contributed to their revival as a space for production and consumption, associated with quality and integrity standards,

The Knowledge of the physical characteristics of these territories, ways of organization, dynamics and socio-economic problems, help to establish a framework of guidance for their development and territorial coordination, which implies the adoption of policies and intervention

\footnotetext{
${ }^{1}$ At present we are witnessing a mountain valuation, which has contributed to the emergence of natural and cultural elements that identify and customize these spaces for centuries, and the strengthening of leisure and entertainment culture that permeates these regions, fosters visitor flows, and diffuses ecocultural values and an image of integrity.
} 


\section{Egitania}

s c i e $\cap$ c i a

strategies, designed its own way. Although valuable territories, the resources they hold, remained outside the guidelines and formal development actions, particularly in Portugal.

It should be noted that tourism is, today, one of the main activities in mountain areas, and, after the coast, the main tourist destination, with a rising importance. Among the attractions stand out the environmental quality, the diversity of ecosystems, the scenic beauty of its landscapes, water resources, forestry and morphological and cultural heritage. It should be noted that the preservation of these areas produces, in addition to safeguarding the natural and cultural heritage, benefits to the surrounding areas in terms of landscape quality, biodiversity conservation and protection of resources and ecological functions (FERNANDES, G., 2008 ). The environmental and economic value of goods and services that the mountain tourism provides to their communities, given the characteristics of ecosystems and physical infrastructure, is a challenge for its planning and management. Recognition of the features and functions of these territories, should foster support to compensate local people, for the effort and minimize the effects of economic competitiveness, and even social, regional and world markets tend, many of them mass markets. Moreover, also the need for financial instruments that foster the creation of appropriate companies for the use and exploitation of mountain resources, including those linked to agriculture, forestry and pastoral system and tourism (Figure 1). It is noted that tourist activities are fostering deeper knowledge of cultural heritage by providing their valuation, conservation and interpretation, allow obtaining revenues. Tourism can also promote and enhance production associated with agriculture, forestry and pastoral system, cultural events and recovery of buildings, enabling the population to stay, creating jobs and complementary activities (Fernandes, G., 2014).

\section{Figure 1 - Structural elements of the mountain heritage dimension}

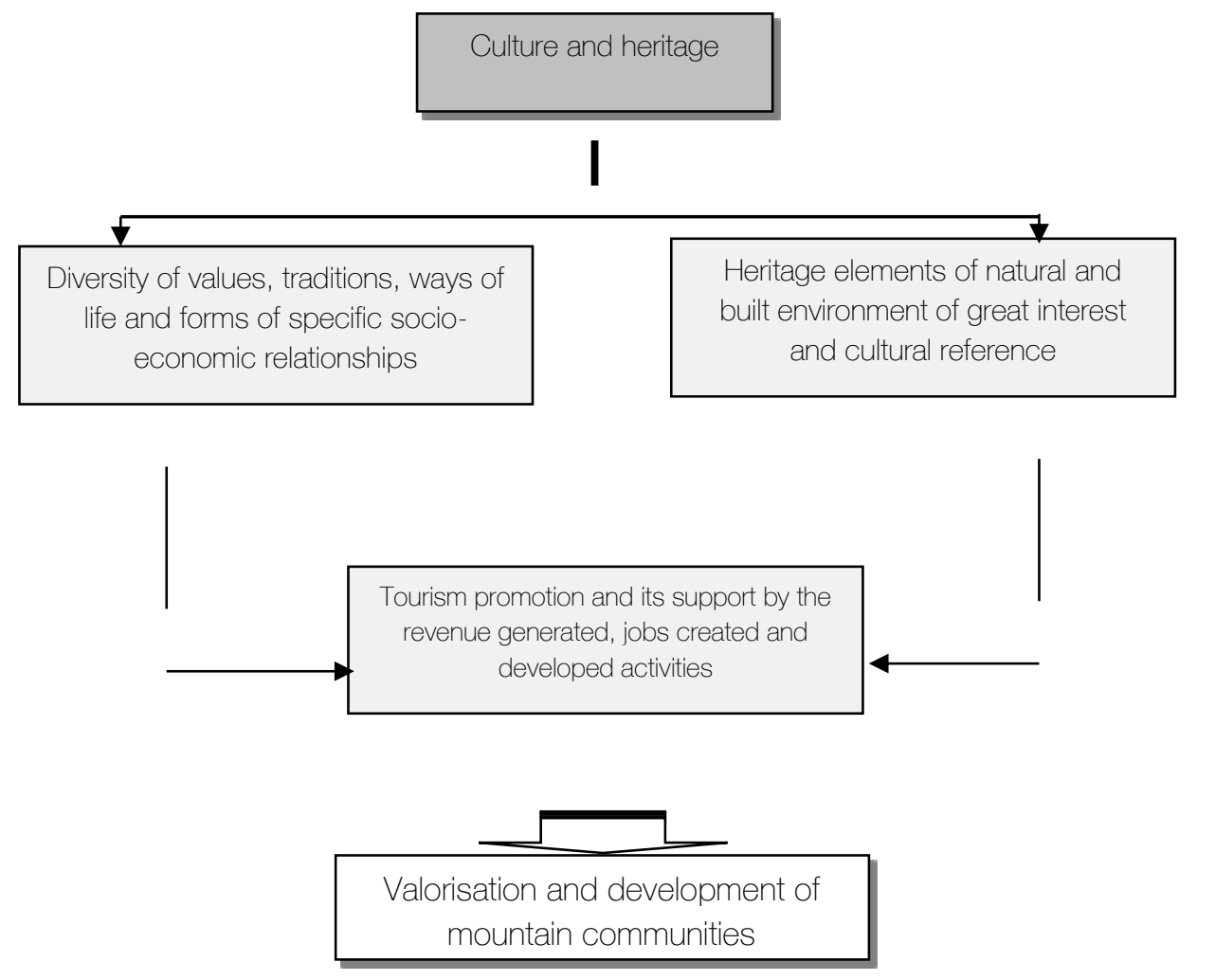




\section{Egitania}

s c i e $\Omega$ c i a

Recognized problems ${ }^{2}$ and weaknesses, require adequate intervention, articulating the coexistence of uses and functions in a scenario tending to change due to the ecological, social and economic role that the mountains represent for communities. According to the Economic and Social Committee (2003), the future of upland areas is inseparable from a specific European policy based on three strands of action:

- Compensation of competitive disadvantages, compared to permanent physical constraints of these territories;

- Increase in equipment and infrastructure to mitigate existing weaknesses and bottlenecks, especially information and communication technologies;

- Development of identity and mountain potentialities, translated into an image of integrity and quality of its resources.

In this sense, the mountain areas require an intervention that will allow them to consolidate their uses and functions and to assume themselves in a fully and valued way, as spaces of authenticity and diversity. The transformations experienced in these areas, especially in the last half century, have led to a differentiated perception with expectations, actors and problems that led to the reconfiguration of the productive bases, social organization and landscapes. Many of its activities were frozen in time, registering to be far from progress models of adjacent territories, especially those of urban nature. Nowadays we witness a general revaluation ${ }^{3}$ of the mountain, in terms of its image, production processes and forms of use, due to the emergence of a new social value system, which rewards the natural and cultural qualities of these territories. These perceptual changes, and even occupation, mean that these areas before isolated and hostile due to natural constraints, today have a vision and distinct ownership as a result of their knowledge and openness. Increased accessibility, use of resources, dissemination of ecoculturais values, the extension of recreation and leisure activities and the increase in visitor flows have contributed to their revival as a space for production and consumption, giving new function to landscapes that had lost its authenticity.

\footnotetext{
2 According to Cavaco, C. (2005, p.2) The mountain areas have special features which accentuate the most marked characteristics of rural areas. Geographical constraints tend to increase the isolation and contribute to the exodus and aging population. Changes in the dominant production systems, once associated mainly with agriculture and forestry, raise the question of viability and sustainability of existing models.

3 However, nowadays we are witnessing a mountain valuation, which has contributed to the emergence of natural and cultural elements that identify and customize for centuries these spaces, and the strengthening of a leisure and entertainment culture that permeates these spaces, fosters visitor flows, spreads ecocultural values and an image of quality
} 


\section{Egitania}

s c i e $\cap$ c i a

\section{THE HERITAGE DIMENSION OF MOUNTAIN AREAS}

The heritage is the memory of the past, it should be preserved the history of the structuring of a territory. In this sense, is important to conserve assets which, apart from its own value, may have social and financial value, ie, strengthen and expand the benefits and economic opportunities for communities. At heritage level, mountains are marked by the geomorphological characteristics, biological diversity, livelihoods, cooperation relations between the communities and the structures developed for agro-pastoral activities. These references have been weakened by negative demographic trends. This regression is especially significant among young people, affecting entrepreneurship and leading to the breakdown of the traditional production base, based on agro-forestry-pastoral system. However, values and traditions associated with their natural and built heritage, structure a differentiated social and territorial model, capable, for its quality and authenticity, to attract new owners and uses, with emphasis on tourism. Tourism activities will foster a better understanding of cultural heritage, providing their appreciation and conservation, allowing incorporate generating functions of social and economic well-being. Tourism can promote certain agro-pastoral productions, cultural events and restoration of the buildings, maintaining population, generates employment and complementary activities.

According to BALLART HERNÁNDEZ, J. e TRESSERRAS, J. (2001) the heritage, nature and of ancient civilizations heritage, is recognized as a superior good that should be protected by national and international institutions. INIESTA, (1990, p.2) states that the heritage is, in itself, a concept that is associated with the history and culture of the local groups, corresponding to the symbolic synthesis of identity values of a society that recognizes them as their own .

Places value their ecocultural assets in order to increase its competitive profile. The heritage stands out as a differentiating feature of territories and strategic element in the design of new products aimed to capture specific segments of tourism demand, fosters group identity of host communities, reinforces feelings of mutual help and cooperation and encourages conservation and sustainable use. Heritage can be constituted as a promotional factor to land valorisation, creating a mark, which enhances its preservation and its strategic consideration in development policies. Thus, it becomes a reference factor of local development, capable of generating territorial balance in terms of attractiveness and activities that generate in its economic and social appropriation. 


\section{Egitania}

s c i e $n$ c i a

\section{APPROACH TO THE COMPARISON OF THE PLANNING AND MANAGEMENT MODELS OF THE MOUNTAINS OF CENTRAL MOUNTAIN RANGE IN PORTUGAL AND SPAIN.}

The models of planning and management of the Iberian Cordillera Central are distinct from one and the other side of the border, depending on the administrative organic, legislative guidelines for territorial planning and classification of protected areas, in force in each State. In both countries this mountainous border set features several mountain ranges whose physical characteristics and ecosystems show continued and even some uniformity (landscape and biological), justifying articulation in its management, in order to effective transnational protection of their natural resources (FERNANDES, G. , 2005 RENGIFO, J., and JIMÉNEZ, V., 2014). In Portugal, have this protection status the Natural Reserve of Serra da Malcata, which continues in Spain with the name Area Natural Sierra de Gata and caza Reserve de las Batuecas, the Serra da Estrela Natural Park and the Spain Park Natural de la Sierra de Francia, the reserve Caza de la Buitrera, the Natural Park of Candelaria, Valle del Jerte and Tiétar (southern slope of Sierra de Gredos).

These territories, in addition to its natural value, represent particular ways of life, with different systems of agricultural and forestry use, revealing a sustainable ownership of the physical elements and resources allowing building landscapes and ecosystems of great cultural value, associated with the diverse existing heritage (CAMPESINO, A., 2014). By its border condition (and peripherals in relation to centers of power) found themselves deprived of key development guidelines of the respective States, which reinforced the socio-economic profile of depressed rural areas, with a production structure based on agro-pastoral sector in crisis and a regressive demographic trend (FUSTER, M., 1998; GASCÓN, J. 2013).

Current law, Portuguese and Spanish, proposes a planning and management model that supports the harmonization of environmental protection with the development of the rural economy of these territories. To this end, planning instruments must provide a link between natural areas and local communities, promoting uses compatible with the conservation of nature and the increasing social and economic base. These mountain areas classified as protected natural areas, require the coordination of efforts between the management bodies, because of their physical condition does not recognize borders, so, the protection of incidents or aggression will be felt as a whole, regardless the country of occurrence. In this sense, the EU itself has had in terms of nature conservation policy, the concern of creating protective measures and specific programs of support and funding for investments relating to the protection of nature and wild fauna and flora. The policy of conservation of natural spaces of the EU based on the Birds Directive ${ }^{4}$ and the Habitats Directive ${ }^{5}$, carried into the Spanish legal system by Royal Decree 1997/1995 and the Portuguese legal system by Decree-Law No. 226/97, determines the basis for a coherent ecological network for the Community, to ensure

4 Directive $79 / 409$ / EEC

5 Directive $92 / 43$ / EEC 


\section{Egitania}

s c i $i$ \& c i a

biodiversity and the conservation of natural habitats, is coming to materialize in the Natura 2000 network, establishing a common system of protection.

In Portugal the process was under the competence of the Institute for Nature Conservation, under the Ministry of Environment, which proposed the list of classified places. In Spain this task fell to the Autonomous Communities, through the appropriate bodies on the environment. The difficulty of applying the management tools of cross-border natural spaces of the Central Cordillera is notorious due to targeted management heritage, primarily for nature protection and planning instruments labelled protectionist, and the socio-economic aspects dealt with partially and economic activities (sometimes even traditional) considered disruptive to nature conservation. These aspects have prevented convert the protection status in a development engine that fosters socio-economic promotion of local communities. However, in the version explain the protection of the environment, the growth of the rural economy, harmonizing social and ecological systems.

To foster the socio-economic development of these areas is essential that the planning model is not limited to prohibition of activities compatible with the protection status and find alternatives to improve the quality of local life. Simultaneously, the protection status should be used to facilitate the adoption of measures and incentives that drive these regions and mitigate the negative connotation in economic and social terms that this classification gives them. In this sense, the Resolution of the Council of Ministers No. 102/96 agrees: coordination of all government departments to establish concrete measures for the sustainable development of protected areas; priority to the adoption of the promotion of economic activities projects; creating jobs compatible with their plans; Maximum reimbursement for projects listed in the National Network of Protected Areas. However, the results have been scarce and the loss of population continues to penalize these territories and to weaken their economic structures.

The collaboration between the two countries and entities responsible for the planning of these spaces is a challenge for its development and promotion, meeting the common environmental and economic problems. A good example is the INTERREG and POCTEP - operational program for development of border regions, which arise in order to strengthen these regions, recognizing its weaknesses. It constitutes an integrated intervention instrument that seeks economic and social improvement of their communities and cross-border coordination of regional development ${ }^{6}$, encouraging cooperation between regional and local bodies.

Within this perspective, the landscape and didactic complementarity of these mountain areas constitute reference elements and potentiation of the border space, which calls for transnational cooperation in order to assume a major role throughout the region and greater projection and valuation within the Community Europe. The meso xerophytic vegetation and

6 CAVACO, C. (1995) refers; the development of border regions should be combined together internally and with the outside, on a regional, national, Iberian and European vision, in a perspective of environmental, economic and social sustainability. This requires interrelated initiatives between the public and private sector, linked with the wishes and needs of the population, preserving productive and cultural activities, setting themselves, connection points and articulation of ancient cross-border cooperation. 
wildlife refuges of the Sierras de Gata and Francia, the nature reserve of Malcata the presence of the Iberian Lynx, the glacial relief of the Serra da Estrela with its imposing and singular forms, are generic traits of ecological and landscape value that according CABERO DIEGUEZ. V. (1997) and FERNANDES, G, (2008), can be converted into a green space of international protection and at present constitute a transnational Geopark.

The autonomous communities of Extremadura and Castile and Lyon have their own laws of spatial planning, which set the guidelines in terms of land use and occupation as well as the instruments of territorial management. Due to its characteristics present in both situations greater management complexity, in the sense that articulate instruments of each community with national guidelines for the various areas of intervention, ie, are complementary to the plans, programs and policies for the regulation of distinct activities established in the corresponding specific legislation, with binding character for the individuals and public administration.

The Community of Extremadura has three types of territorial planning instruments: Directrices Territorial Ordenación, Planes Territoriales, Proyectos de Interés Regional hierarchically articulated, albeit with administrative scales and own intervention guidelines. The Ley del Suelo y Ordenación del Territorio de Extremadura and the Urban Planning Reglamento establish the guiding instruments of territorial organization model, giving directions for a policy that defines and prioritises measures to prevent the consolidation of spatial dysfunctions and allow the reorientation of concentration trends in the economy in a few urban centers, which polarize the regional territory. Simultaneously identify a set of guidelines whose objectives may be summarized in:

- Defend and protect spaces, resources and natural elements, ecological systems and landscapes;

- Use rationally the space of agricultural value, livestock and forestry, with special consideration for the agricultural areas of mountain, to provide their social and economic requalification, seeking to conserve the customs and traditional practices compatible with the environment;

- Contribute to the rational distribution of water resources, control of basins and protection of water quality;

- Ensure the sustainable exploitation of natural resources, especially mining and energy;

- Preserving the historical, cultural and artistic heritage in urban and rural areas, promoting their recovery, rehabilitation and enrichment;

- Maintain and improve the quality of urban life by regulating land use and access to equipment and services on equal terms;

Integrate and harmonize public and private sector, sectorial or specific interests affecting in a relevant way the territory. 


\section{Egitania}

s c i e $\Omega$ c i a

In Castilla y Léon community are defined four types of instruments: Directrices de Ordenación del Territorio de Castilla y León, Directrices de Ordenación de ámbito sub-regional, Planes and Proyectos Regionales. In practice, this law establishes a system of planning tools to address the shortcomings of urban development plans and sectoral planning policies, particularly in the resolution of supra-municipal scope of problems and proper coordination of actions with a territorial impact. Its intervention seeks to achieve the following objectives:

-Define a territorial model that can encourage reconciliation and integration of the entire territory and increase their connection to the outside of the Community, with particular attention to the potential nuclei to develop into regional development centers.

- Improve compatibility between the production system development processes, urbanization and the protection of the environment and cultural heritage of the Community.

- Establish criteria and procedures to ensure coordination of actions with a territorial impact, provided an overview of the Autonomous Community issues.

On the whole the mountainous areas of the Central Cordillera have the following guidelines for land management:

- classification as protected areas with their own status in Spain and Portugal;

- implementation of EU directives that led to its classification under the Natura net;

- implementation of national Spatial Planning within the sectoral scope (forestry, transportation, energy, environment ...);

- definition of occupation types based on the Municipal Master Plans in Portugal and Planning Instrument defined by the Autonomous Communities of Castilla y Leon and Extremadura.

In practice is found similarity of performance in both countries in the management of mountain areas classified as protected areas, which favours its protection and integration in Natura 2000. However, the autonomous communities recognize the mountainous specificity and link particular interventions that requalify, trying to preserve traditional practices of land use and livelihoods. So far, cooperation has been held mostly informal, under different land management capacity of these spaces. In Spain has a regional dimension and in Portugal the management model is centralized and regional specificities were not integrated until the moment in regional plans.

In short the planning interlocutor entities of these spaces reveal differences in formats that support their intervention, existing in Spain greater autonomy and regionalist character, a recognition of mountain specificity and integrated participation of different administrative bodies, albeit with some complexity introduced by differentiations established by the various autonomous regions. In Portugal the ICNF - Instituto de Conservação da Natureza e Florestas is responsible for its management, as well as Natura, with processes of lower participation of 
local communities, and the development plans of these areas supported mainly on environmental principles, despite the reference to recovery of livelihoods and traditional activities. This simplicity of operation may become advantageous in the management of these territories where it involves local communities is recognized the territorial specificity, in addition to ecological and geomorphological values which formed the basis of their classification.

The ordering of these territories will have to assume the passage of a vision of "border separation" to a vision of "border-cooperation" in which the territorial management tools have the capacity to articulate, through spaces that have similar characteristics and process development. In this sense should lie with PROT's - Plano Regional de Ordenamento do Território, as regional instruments of regional planning, the recognition of territorial cooperation such as with the Autonomous Spanish Regions common management guidelines, able to devise a model that strengthens cooperation between Portuguese municipalities and the Spanish provinces, strengthening the link (physical and communication accessibilities), matching uses and functions and establishing common projects. In the case of the Cordillera Central the establishment of an Iberian Natural Park (Geopark) could provide an effective solution to the planning of this territory, articulating a global model for the management and valuation of ecosystems. This process would involve territorial delimitation and a guiding regulation of management tools in both countries, without involving their disarticulation. If their instrumentation can be designed in a peaceful manner, its governance may prove to be the most complex process, for historical, political and economic reasons. The creation of a management entity represented by the regions, the ICNF and the Ministry del Ambiente, could, given the integration of local and state power, to be the most appropriate, in that the very areas classified in both countries would thus be contemplated and safeguarded, in terms of their specificity, but simultaneously integrated into a cross-border territorial management model.

\section{CONCLUSION}

Mountain areas are seen today revalued by their Ecocultural potential, making it attractive to the landscape, environmental and historical-cultural level for tourist activities Tourism is gaining significance in local policies and investments, being perceived as dynamic and polarizing activity wealth. The oldest border of Europe offers secular history, geography of different landscapes, natural resources with unique ecosystems and a military and religious heritage of relief, which its development and promotion depend mainly on the implemented planning model, which should figure more prominently to articulate the effective participation of the agents involved, streamline and regulate the activity. It is necessary to promote planning tools sets, with articulated appreciation of space strategies that go beyond the administrative division and contribute to the quality of life in communities. 


\section{Egitania}

s c i e n c i a

The emergence of a new social and cultural system connected to the urban society is the basis of current occupancy trends of mountain areas and their valuation. Tourism activities are revealed as the most dynamic in the appropriation of space and the economic structure of these regions fostered the emergence of services related to catering, sports and leisure. The development and promotion of heritage, the recovery of property and traditions, the development of products from agriculture and pastoralism, interest in sporting activities related to water resources and forest and the tranquillity and purity associated increment the potential demand for these destinations in the national and international context. However, there are strategic management problems, resulting from its not efficient valorisation and promotion by the local administrative structures. It is necessary to develop initiatives to enhance awareness of the different potential of mountain regions, promote their space, their culture and economy, claim a specific development model, in which tourism is favourable to its expansion with maintenance of communities and local ways of life. 


\section{Egitania \\ s c i e $\cap$ c i a}

\section{BIBLIOGRAPHY}

AEM (2003) - APPEL A LA CONVENTION EUROPEENNE POUR UNE OBJECTIF DE COHESION TERRITORIAL DANS LE FUTUR TRAITE CONSTITUTIONNEL, AEM, BRUXELES.

Ballart herNANDEZ, J.;TRESSerRAS, J.,(2001). Gestión del patrimonio cultural. Coleccion Ariel Patrimonio. Barcelona: Ariel. 224PP.

BARRUet, J. (1995) - "Polttique de la mOntagne. L'enjeu europeen et transfrontalier", in BARRUet, J. (Coord), MONTAGne LABORATOIRE DE LA DIVERSITE, CEMAGREF, P. 227-238, GRENOBLE.

CABero dieguez, V. (1994) - El espacio fronterizo de Salamanca con Portugal. Una aproximacion geográfica y SOCIOECONOMICA, UniverSidAde de SAlamanCA, SalamanCA.

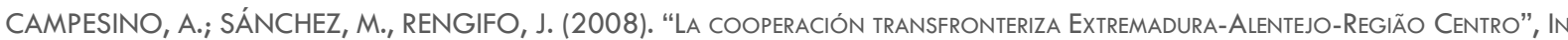
domínguez, L. (Dir.). A CoOperaçao transfronteirlça entre Portugal e Espanha, (Pp. 235-259). Vigo:Eixo Atlántico do NOROESTE PENINSULAR.

CAIRO, H., LOIS, M. (2011 1). DesfronterizaCión y refronterización en la Península IbériCA. GeOpolítica(s), 1, 11 - 22.

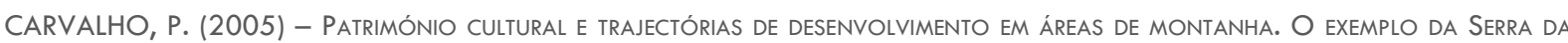
LOUSÃ, TESE de Doutoramento, UNIVERSIDADE de CoImbra.

COMISSÃO EUROPEIA (2004) - MOUNTAIN AREAS IN EUROPE: ANALYSIS OF MOUNTAIN AREAS IN EU MEMBER STATES, ACCEDING AND OTHER EUROPEAN COUNTRIES - FINAL REPORT, BRUXELES.

COMItÉ ECONÓMICO E SOCIAL (2003), El futURo de las ZONAS de MONTAÑA EN LA UNIÓN EUROPEA, CES (2003/C61/19), BRUSELAS. CUNHA, L. (2003) - " A MONTANHA DO CENTRO PORTUGUÊS: ESPAÇO DE REFÚGIO, TERRITÓRIO MARGINAL E RECURSO PARA O DESENVOLVIMENTO local”, in Caetano, l. (Coord.), Território, Ambiente e trajectórias de Desenvolvimento, Centro de Estudos Geográficos, UNIVERSIDADE de CoIMBRA, COIMBRA.

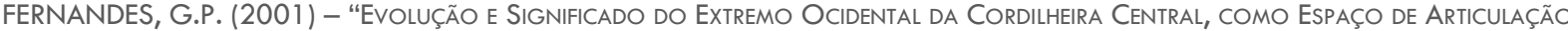

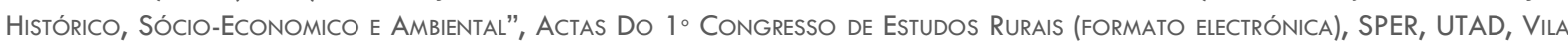
REAL.

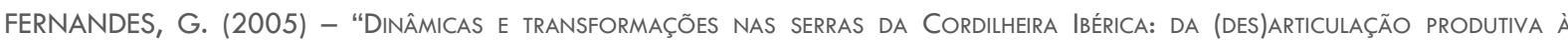
(Re)Valorização ecocultural", In JACINTO, R e Bento, V. (CoOrd.), Territórios e Culturas Ibéricas, P. 60-74, Campo das Letras, PORTO.

FERNANDES, G. (2014) - SIGNIFICADO DO TURISMO EM REGIÕES DE FRONTEIRA E SUA PROMOÇÃO - O CASO DA REGIÃO CENTRO DE PORTUGAL COM CASTILLA Y LEÓN E EXTREMAdURA EM ESPANHA, IN CAMPESINO FERNÁNDES, A. (EDITOR): TURISMO DE FRONTERA (II) OFERTA Y DEMANDA TURíSTICA EN LA RAYA IBÉRICA , PP. 309-322, CÁCERES (ISBN: 978-84-695-9766-8)FUSTER, M (1998) - "APROXIMACIÓN A LA COMPARCION DE LOS MODELOS DE GESTIÓN DE LOS ESPACIOS NATURALES PROTEGIDOS EN ÁREAS TRANSFRONTERIZAS : LA RAYA HISPANO-LUSA", Cuadernos de Ordenacion del Território, №2, p. 50-60, Fundicot, CÁCeres.

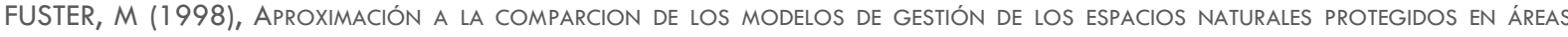
transfronterizas : la raya hispano-lusa, Cuadernos de Ordenacion del Território, № 2, P. 50-60, Fundicot, CáCeres.

GASCÓN, J. (2013) "THE LIMITATIONS OF COMMUNITY-BASED TOURISM AS AN INSTRUMENT OF DEVELOPMENT COOPERATION: THE VALUE OF THE Social Vocation of the Territory concept”. Journal of Sustainable TOURISM. Vol. 21, No.5: 716-731.

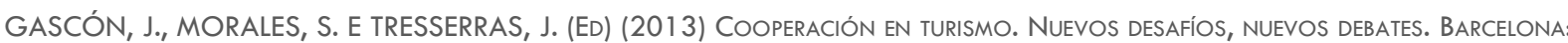
FORO TURISMO RESPONSABLE.

Gaskell, F. (2005) - "Áreas de montanha têm Vantagem no mercado global", Jornal Pessoas e lugares - Territórios de MONTANHA -, II SÉRIE, № 28, P.4-5, IDRHA, LISBOA.

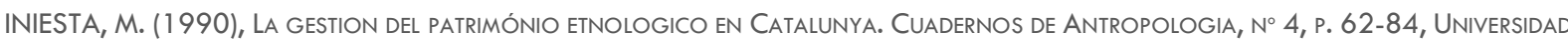
de Catalunya, Barcelona.

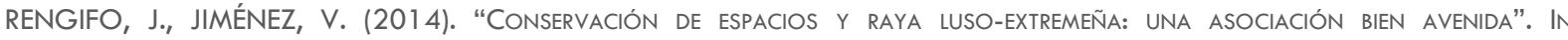
CAMPESINO, A. (DIR.). (2014). TURISMO de Frontera (II), (PP. 47-82). CÁCERES, AUtOres. 